\title{
Minimally invasive video-assisted mitral valve surgery: A 12-year, 2-center experience in 1178 patients
}

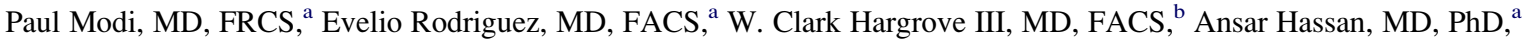 \\ Wilson Y. Szeto, MD, FACS, ${ }^{\text {and W. Randolph Chitwood, Jr, MD, FACS, FRCS }}{ }^{\mathrm{a}}$
}

Objective: To review a 2-institution experience with minimally invasive mitral valve surgery over a 12-year period.

\begin{abstract}
Methods: We prospectively collected data on all patients having minimally invasive mitral valve surgery through a right minithoracotomy between May 1996 and May 2008.

Results: A total of 1178 patients included 941 (79.9\%) patients having mitral valve repair and $237(20.1 \%)$ having mitral valve replacement. The mean age was $61.1 \pm 13.9$ years, mean ejection fraction was $52.8 \% \pm 12.1 \%$, and 221 patients $(18.8 \%)$ were having reoperations. Operative mortalities for mitral valve repair and mitral valve replacement were $2.1 \%$ and $4.6 \%$, and for isolated primary MVP and MVR were $0.2 \%$ and 3.6\%, respectively. Repair techniques included annuloplasty (98.2\%), leaflet resection (40.7\%), sliding plasty $(21.0 \%)$, chordal transfer $(9.0 \%)$, and neochordae placement $(7.4 \%)$, with no or trivial residual MR in over $97 \%$ of patients. In patients having mitral valve replacement, a bioprosthesis was placed in 101 patients $(42.6 \%)$ and a mechanical valve in $136(57.4 \%)$. Concomitant procedures included atrial fibrillation ablation $(22.5 \%)$, tricuspid valve surgery $(5.4 \%)$, and atrial septal defect closure $(9.4 \%)$. Nineteen patients $(1.6 \%)$ experienced intraoperative conversion to sternotomy. Twenty-two patients $(1.9 \%)$ had a reoperation at a mean of $732 \pm 1014$ days. Independent predictors of in-hospital mortality included New York Heart Association class III/IV (odds ratio 3.62), diabetes (odds ratio 2.81), bypass time $>180$ minutes (odds ratio 2.63), preoperative atrial fibrillation (odds ratio 2.53), and age $>70$ years (odds ratio 2.29). Prior cardiac surgery was not a significant predictor of mortality.
\end{abstract}

Conclusions: Video-assisted mitral valve surgery is safe with high rates of repair, low morbidity, and excellent outcomes. Reoperation after previous median sternotomy is not an independent predictor of mortality with this approach. Operative risk is increased if surgery is delayed until the onset of atrial fibrillation.

Because of excellent clinical results, minimally invasive mitral valve surgery (MIMVS) has evolved since the mid1990s and has become the preferred method of mitral valve repair (MVP) and mitral valve replacement (MVR) at certain specialized centers worldwide. MIMVS refers to a collection of new techniques and operation-specific technologies, such as modified perfusion methods and visualization techniques that are directed toward minimizing surgical trauma. The belief that this approach leads to less pain, shorter hospital stays, faster return to normal activities, superior cosmesis, and potential cost savings has driven this development. ${ }^{1,2}$ However, some surgeons still express concern that restricted exposure, limited operating space, and longer instruments may lead to inferior results both in ability to repair the valve and long-term outcomes. ${ }^{3}$

Since 1996, surgeons at East Carolina University and the University of Pennsylvania have had a large experience with

\footnotetext{
From the East Carolina Heart Institute, ${ }^{\text {a }}$ East Carolina University, Greenville, NC, and Penn Presbyterian Medical Center, ${ }^{\mathrm{b}}$ University of Pennsylvania, Philadelphia, Pa. Received for publication Sept 17, 2008; revisions received Oct 21, 2008; accepted for publication Nov 21, 2008

Address for reprints: W. Randolph Chitwood, Jr, MD, FACS, FRCS, East Carolina Heart Institute, East Carolina University, Pitt County Memorial Hospital, 600 Moye Boulevard, Greenville, NC, 27834 (E-mail: chitwoodw@ecu.edu). J Thorac Cardiovasc Surg 2009;137:1481-7 $0022-5223 / \$ 36.00$

Copyright (C) 2009 by The American Association for Thoracic Surgery doi:10.1016/j.jtcvs.2008.11.041
}

video-assisted mitral valve surgery through a $4-\mathrm{cm}$ right minithoracotomy. The aim of this study was to review our collective early results and to examine the safety, efficacy, and early outcomes of MIMVS.

\section{METHODS \\ Patients}

We prospectively collected pre-, intra-, and postoperative data on all patients who had video-assisted mitral valve surgery at East Carolina University between May 1996 and April 2008 and the University of Pennsylvania between November 1998 and October 2007. During this period, all patients referred with mitral valvular disease were considered for video-assisted mitral valve surgery. Absolute contraindications to this approach included severe peripheral vascular disease, a history of a prior right-sided thoracotomy/irradiation, concomitant coronary artery disease requiring surgical revascularization, or concomitant aortic valvular disease requiring replacement. As this was our standard approach, Institutional Review Board approval was not needed, but standard informed consent regarding surgical approach and expected outcomes was obtained by either the operating surgeon or team. Patients having robotic mitral valve surgery using the da Vinci ${ }^{\circledR}$ system (Intuitive Surgical Inc, Mountain View, Calif) were excluded from this analysis.

\section{Surgical Technique}

Our surgical approach has been described previously ${ }^{4,5}$ and is summarized here. Each operation was performed through a 4-cm working incision made in the right infrathoracic groove and carried through the fourth intercostal space. Rib spreading was limited by using small thoracic and soft tissue retractors. Each patient had double-lumen endotracheal intubation 


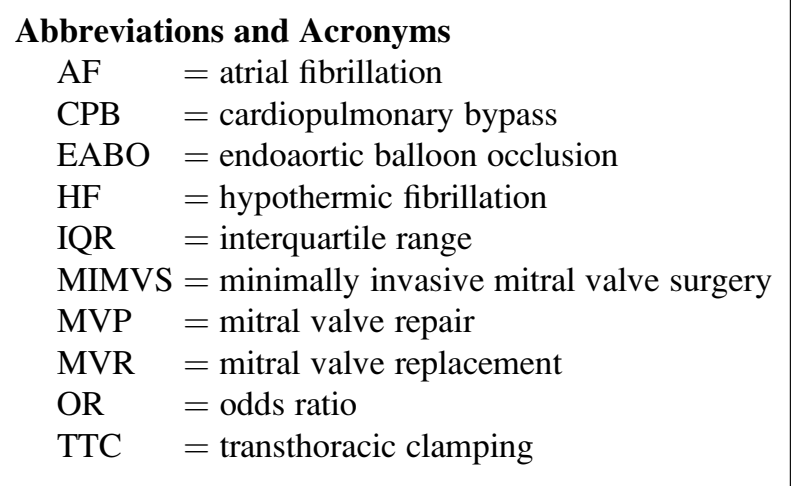

followed by a transesophageal echocardiography study. To minimize intracardiac air retention, the pleural cavity was flooded continuously with $\mathrm{CO}_{2}$. Vacuum-assisted femoral-femoral cardiopulmonary bypass (CPB) was used with upper-body venous return augmented through a $15 \mathrm{~F}$ to $17 \mathrm{~F}$ right internal jugular cannula positioned in the superior vena cava. For primary procedures, aortic occlusion was accomplished by either transthoracic clamping (TTC) or endoaortic balloon occlusion (EABO), according to surgeon preference. For reoperative cases, either hypothermic fibrillation (HF) or EABO was used. Hypothermic $\left(28^{\circ} \mathrm{C}\right)$ perfusion and cold $\left(4^{\circ} \mathrm{C}-6^{\circ} \mathrm{C}\right)$ antegrade cardioplegic solution, administered at 15 - to 20 -minute intervals, were used for systemic and myocardial protection. When necessary, retrograde cardioplegic solution was administered through a transjugular or transthoracic coronary sinus catheter. Long-shafted instruments were used to perform each operation (Geister, Plymouth, Mass).

Operative visualization was through a 5-mm endoscope, passed through an anterior axillary line fourth intercostal space trocar. A left atriotomy (Waterston's interatrial groove) was made, and MVPs were done using standard Carpentier techniques. Posterior, anterior, and bileaflet prolapsing valves were repaired in this series. MVR was performed with interrupted pledgetted 2-0 Ticron (Tyco Healthcare, Mansfield, Mass) mattress sutures using both biologic and mechanical valves. Cardiac deairing was performed by flushing the left atrium across the atrial suture line as well as aortic root venting. Echocardiography ensured intracardiac air removal and was used to monitor valve and ventricular function.

\section{Statistical Analysis}

Descriptive statistics were reported using means \pm standard deviations, medians \pm interquartile ranges (IQRs), and proportions. Comparisons of data between groups were carried out using either a 2-sided $t$ test or the Kruskal-Wallis test for continuous data and $\chi^{2}$ or Fisher exact test for categorical data. A nonparsimonious, multivariate logistic regression model was constructed on the basis of pre- and intraoperative variables to determine predictors of in-hospital mortality with the odds ratio (OR) of each predictor serving to quantify its relative effect on mortality. A C-statistic for the model was generated to assess the ability to discriminate between patients with the adverse outcome of interest and those without any. All analyses were performed using SAS version 9.1.3 (SAS Institute, Cary, NC).

\section{RESULTS}

A total of 1178 patients had a minimally invasive mitral valve procedure (University of Pennsylvania, 634; East Carolina University, 544). MVP was performed in 941 patients (79.9\%) and MVR in 237 patients (20.1\%). Preoperative patient characteristics and echocardiographic data are shown in Table 1. Patients having MVR had a higher risk profile compared with patients having MVP, with a greater proportion having mitral stenotic or mixed disease.

Mean aortic occlusion and CPB times were $99.8 \pm 37.6$ minutes and $142.1 \pm 47.1$ minutes for MVP procedures and $115.3 \pm 49.7$ minutes and $162.1 \pm 63.4$ minutes for MVR patients, respectively (Table 2). Concomitant procedures were performed in 390 patients $(33.1 \%)$ and included atrial fibrillation (AF) ablation in 265 patients $(22.5 \%)$, tricuspid valve surgery in 64 patients $(5.4 \%)$, patent foramen ovale/atrial septal defect closure in 111 patients $(9.4 \%)$, and oversewing of the left atrial appendage in 114 patients $(9.7 \%)$.

The transthoracic clamp was used in 573 patients $(48.7 \%), \mathrm{EABO}$ in 479 patients $(40.7 \%), \mathrm{HF}$ in 120 $(10.1 \%)$, and TTC + HF in $6(0.5 \%)$. Compared with TTC, prior cardiac surgery was more common and operative times were longer with EABO but the rate of valve repair was similar (Table 3). The incidence of stroke with EABO was $2.7 \%$ versus $1.2 \%$ with TTC $(P=.08)$. There were 7 aortic dissections $(1.5 \%)$ with the endoballoon (type A, $\mathrm{n}=4$; type $\mathrm{B}, \mathrm{n}=3)$ and $2(0.4 \%)$ with the transthoracic clamp (type $\mathrm{A}, \mathrm{n}=2 ; P=.09$ ). All patients with a type $\mathrm{B}$ dissection survived without neurologic deficit, whereas 2 of those with type A dissection died (mortality 33\%) and 1 further patient had a stroke. There was a significantly higher rate of conversion to sternotomy and longer hospital stay with EABO although no significant difference in mortality.

Among patients having an MVP, repair techniques included a ring annuloplasty in 924 patients $(98.2 \%)$ with a median ring size of $30 \mathrm{~mm}$ (IQR $28-34 \mathrm{~mm}$ ), Carpentier-type leaflet resection in 383 patients $(40.7 \%)$, sliding plasty in 198 patients $(21.0 \%)$, chordal transfer in 85 patients $(9.0 \%)$, and polytetrafluoroethylene neochordae placement in 70 patients $(7.4 \%$; Table 4$)$. The intraoperative transesophageal echocardiogram demonstrated that $97.1 \%$ of patients having MVP for MR left the operating room with no more than trivial residual MR (Table 5). In patients having MVR, a bioprosthesis was placed in 101 (42.6\%) and a mechanical valve in $136(57.4 \%)$.

Nineteen patients $(1.6 \%)$ had intraoperative conversion to sternotomy (MVR 6, MVP 13), the reasons being: type A aortic dissection $(n=6)$, atrioventricular groove disruption $(n=6)$, circumflex artery injury $(n=2)$, severe mitral annular calcification $(\mathrm{n}=1)$, contralateral tension pneumothorax $(\mathrm{n}=1)$, aortoinnominate junction injury $(\mathrm{n}=1)$, difficult aortic occlusion $(\mathrm{n}=1)$, and other $(\mathrm{n}=1)$.

\section{Postoperative and Midterm Outcomes}

Overall operative mortalities for MVP and MVR were $2.1 \%$ and $4.6 \%$, respectively. Mortalities for isolated MVP and MVR were $0.8 \%$ and $3.9 \%$ and for isolated primary MVP and MVR were $0.2 \%$ and 3.6\%, respectively. 
TABLE 1. Preoperative clinical and echocardiographic characteristics

\begin{tabular}{|c|c|c|c|c|}
\hline Variable & Overall $(n=1178)$ & Repair $(n=941)$ & Replacement (n = 237) & $P$ value \\
\hline Age, y (mean \pm SD) & $61.1 \pm 13.9$ & $60.8 \pm 13.9$ & $62.6 \pm 13.7$ & .06 \\
\hline Female sex $(\%)$ & 51.0 & 47.7 & 64.1 & $<.0001$ \\
\hline Previous cardiac surgery & 18.8 & 13.2 & 40.9 & $<.0001$ \\
\hline Diabetes $(\%)$ & 11.5 & 11.1 & 13.5 & .51 \\
\hline Hypertension (\%) & 44.8 & 43.8 & 49.0 & .15 \\
\hline Pulmonary hypertension (\%) & 35.7 & 31.1 & 54.0 & $<.0001$ \\
\hline Preoperative atrial fibrillation & 36.5 & 35.5 & 40.5 & .15 \\
\hline Congestive heart failure $(\%)$ & 60.5 & 55.9 & 78.9 & $<.0001$ \\
\hline NYHA class III/IV (\%) & 43.9 & 38.6 & 65.0 & $<.0001$ \\
\hline \multicolumn{5}{|l|}{ Echocardiographic findings } \\
\hline \multicolumn{5}{|l|}{ Mitral regurgitation } \\
\hline None $(\%)$ & 1.4 & 0.3 & 5.5 & \\
\hline Trivial $(\%)$ & 0.4 & 0.2 & 1.3 & \\
\hline Mild (\%) & 2.4 & 1.7 & 5.1 & \\
\hline Moderate (\%) & 7.8 & 6.8 & 11.8 & \\
\hline Severe $(\%)$ & 88.0 & 91.0 & 76.4 & $<.0001$ \\
\hline Mitral stenosis (\%) & 9.9 & 2.2 & 40.1 & $<.0001$ \\
\hline \multicolumn{5}{|l|}{ Tricuspid insufficiency } \\
\hline None $(\%)$ & 58.8 & 60.2 & 53.6 & \\
\hline Trivial $(\%)$ & 2.8 & 3.2 & 1.3 & \\
\hline Mild (\%) & 20.5 & 20.9 & 19.0 & \\
\hline Moderate $(\%)$ & 12.7 & 11.4 & 17.7 & \\
\hline Severe $(\%)$ & 5.2 & 4.4 & 8.4 & .003 \\
\hline Ejection fraction (mean) & $52.8 \pm 12.1$ & $52.4 \pm 12.1$ & $54.1 \pm 11.9$ & .05 \\
\hline Ejection fraction $<50 \%(\%)$ & 26.7 & 28.0 & 21.9 & .06 \\
\hline
\end{tabular}

NYHA, New York Heart Association functional class; $S D$, standard deviation.

Reoperation for bleeding was required in 63 patients $(5.4 \%)$, with the same video-assisted approach used in all patients without the need for conversion to sternotomy. Postoperative strokes were observed in 23 patients $(2.0 \%)$. Median hospital stay was 6 days (IQR 5-8 days). Other complications are shown in Table 6. Twenty-two patients $(1.9 \%)$ had a reoperation at a mean of $732 \pm 1014$ days as the result of either recurrent severe MR $(n=13)$, endocarditis $(n=3)$, recurrent severe MS $(n=2)$, valve dehiscence $(\mathrm{n}=2)$, systolic anterior motion $(\mathrm{n}=1)$, or hemolysis $(\mathrm{n}=1)$.

Multivariate logistic regression modeling revealed that New York Heart Association functional class III/IV, diabetes, $\mathrm{CPB}$ time $>180$ minutes, preoperative $\mathrm{AF}$, and age $>70$ years were independent predictors of mortality, whereas previous cardiac surgery was not (Table 7 ). The C-statistic of the model was 0.86 .

\section{DISCUSSION}

This series comprises our total experience, including our learning curve, of minimally invasive video-assisted mitral valve surgery from May 1996 until May 2008. The in-hospital mortalities of $0.8 \%$ and $3.9 \%$ for isolated MVP and MVR, respectively, are lower than the reported operative mortality rates in the Society of Thoracic Surgeons Fall 2007 report $\left(1.6 \%\right.$ and $6.1 \%$, respectively). ${ }^{6}$ The mortality figures in our series are also concordant with other reports of the same technique ranging from $0.4 \%$ to $2.4 \%$ for MVP and from $2.5 \%$ to $5.8 \%$ for MVR. ${ }^{7-10}$

Critics of MIMVS suggest that MVP may be performed less frequently and that the repair may be less durable than that obtained through a sternotomy. The greater degree of difficulty presented by limited operating space, long instruments, and video assistance are cited as reasons for this opinion. ${ }^{7}$ Overall, $79.9 \%$ of our patients had a repair; however, of those having a repair for MR, our repair rate was $86.6 \%$. This is similar to the series reported by Seeburger and colleagues $^{7}$ (1536 patients, 87.2\%), Aybek and associates ${ }^{11}$ (241 patients, 83\%), Casselman and coworkers ${ }^{8}$ (306 patients, 74\%), and Grossi's group 9 (561 patients, 66.8\%), using the right minithoracotomy approach; and Mihaljevic and colleagues $^{12}$ (474 patients, 88\%), using the lower hemisternotomy; or Suri and associates ${ }^{13}$ (1411 patients, $83 \%$ ), using a median sternotomy. This clearly demonstrates that this technique is reproducible with repair rates comparable to both conventional surgery and other minimally invasive approaches with over $97 \%$ of patients leaving the operating room with no more than trivial residual regurgitation. Thus, the early results of repair are clearly not compromised by this less invasive approach. In terms of durability, a reoperative rate of $1.9 \%$ at just over 2 years is consistent with published sternotomy repair data. ${ }^{13}$ 
TABLE 2. Procedural details

\begin{tabular}{|c|c|c|c|c|}
\hline Variable & Overall $(n=1178)$ & Repair $(n=941)$ & Replacement $(\mathbf{n}=\mathbf{2 3 7})$ & $P$ value \\
\hline \multicolumn{5}{|l|}{ Valve replacement type } \\
\hline Bioprosthetic $(\%)$ & - & - & 42.6 & \\
\hline Mechanical (\%) & - & - & 57.4 & \\
\hline $\mathrm{CPB}$ time, $\min ($ mean $\pm \mathrm{SD})$ & $146.1 \pm 51.4$ & $142.1 \pm 47.1$ & $162.1 \pm 63.4$ & $<.0001$ \\
\hline CPB time $>180 \min (\%)$ & 18.7 & 16.6 & 27.0 & .0002 \\
\hline Aortic occlusion time, min (mean $\pm \mathrm{SD})$ & $104.6 \pm 40.3$ & $99.8 \pm 37.6$ & $115.3 \pm 49.7$ & $<.0001$ \\
\hline Hypothermic fibrillation, min (mean \pm SD) & $101.4 \pm 44.1$ & $91.7 \pm 36.1$ & $118.8 \pm 51.9$ & .004 \\
\hline \multicolumn{5}{|l|}{ Additional procedures $(\%)$} \\
\hline Tricuspid valve repair/replacement & 5.4 & 5.4 & 5.5 & .97 \\
\hline ASD/PFO closure & 9.4 & 11.1 & 3.0 & .0001 \\
\hline Maze/ablation & 22.5 & 24.9 & 13.1 & .0001 \\
\hline Left atrial appendage exclusion & 9.7 & 10.4 & 6.8 & .09 \\
\hline \multicolumn{5}{|l|}{ Myocardial protection technique (\%) } \\
\hline Transthoracic clamp & 48.7 & 48.7 & 48.5 & \\
\hline Endoaortic balloon occlusion & 40.7 & 43.0 & 31.2 & \\
\hline Hypothermic fibrillation & 10.1 & 8.0 & 19.8 & \\
\hline Hypothermic fibrillation + clamp & 0.5 & 0.3 & 0.4 & $<.0001$ \\
\hline Conversion to sternotomy $(\%)$ & 1.6 & 1.4 & 2.5 & .21 \\
\hline
\end{tabular}

The increased operative risk associated with advanced age is ubiquitous in surgical articles ${ }^{14}$; however, the importance of a reoperative sternotomy has been deemphasized. ${ }^{15-17}$ In a multivariate logistic regression model of 409,904 valve procedures performed between 1994 and 2003 and cataloged in the Society of Thoracic Surgeons database, the third most important preoperative variable influencing operative mortality was a reoperation (OR 1.61, $P<.001) .{ }^{18}$ However, our data suggest that a right minithoracotomy approach after previous median sternotomy is not an independent predictor of mortality (OR 1.13, $P=.77$ ). This important finding sug-

TABLE 3. Comparison of endoaortic balloon occlusion to transthoracic clamping

\begin{tabular}{|c|c|c|c|}
\hline Variable & EABO & TTC & $P$ value \\
\hline $\mathrm{n}$ & 479 & 573 & \\
\hline $\begin{array}{c}\text { Previous cardiac } \\
\text { surgery }(\%)\end{array}$ & 15.0 & 6.6 & $<.0001$ \\
\hline CPB time (min) & $149.0 \pm 53.2$ & $142.2 \pm 48.8$ & .03 \\
\hline $\begin{array}{l}\text { Aortic occlusion time } \\
\quad(\min )\end{array}$ & $112.0 \pm 43.8$ & $99.4 \pm 35.8$ & $<.0001$ \\
\hline $\begin{array}{l}\text { Mitral valve repair rate } \\
\qquad(\%)\end{array}$ & 84.6 & 79.9 & .051 \\
\hline Permanent stroke & 2.7 & 1.2 & .08 \\
\hline Reoperation for bleeding & 6.7 & 4.7 & .17 \\
\hline Aortic dissection & 1.5 & 0.4 & .09 \\
\hline Conversion to sternotomy & 2.9 & 0.9 & .01 \\
\hline $\begin{array}{l}\text { Hospital length of stay } \\
\text { (days), median (IQR) }\end{array}$ & $7(5-8)$ & $5(4-7)$ & $<.001$ \\
\hline Mortality (\%) & 1.5 & 2.3 & .34 \\
\hline
\end{tabular}

gests that, in terms of early outcomes, this should be the technique of choice for reoperative mitral valve surgery in patients who do not need a concomitant aortic valve replacement or coronary revascularization. This is concordant with data demonstrating equivalent or lower mortality rates and less morbidity for a right minithoracotomy approach versus a reoperative sternotomy. ${ }^{19-21}$ However, data on mid- and long-term outcomes are needed.

Patients with AF frequently present with more severe symptoms with increased cardiac morbidity in the form of a prior myocardial infarction, cardiomegaly, tricuspid valve regurgitation, and/or pulmonary hypertension. Prior nonsurgical series have identified $\mathrm{AF}$ as a marker of severe cardiac disease and a specific risk factor for decreased long-term survival. $^{22,23}$ Moreover, numerous surgical series have documented poorer long-term outcomes in patients with AF having mitral valve,${ }^{24-27}$ coronary,${ }^{28}$ or aortic valve surgery. ${ }^{29}$ The influence on both short-term outcomes and operative mortality has hitherto been less clear. Both Lim and associates ${ }^{25}$ and Chua and colleagues ${ }^{30}$ demonstrated no difference in operative mortality for patients with $\mathrm{AF}$

TABLE 4. Details of mitral valve repair technique

\begin{tabular}{lcc}
\hline \multicolumn{1}{c}{ Valve repair technique } & n & \% of 941 \\
\hline Annuloplasty & 924 & 98.2 \\
Median ring size (IQR), mm & $30(28-34)$ & - \\
Leaflet resection & 383 & 40.7 \\
Sliding plasty & 198 & 21.0 \\
Chordal shortening & 9 & 1.0 \\
Chordal transfer & 85 & 9.0 \\
Polytetrafluoroethylene chordal placement & 70 & 7.4 \\
\hline
\end{tabular}

$I Q R$, Interquartile range. 
TABLE 5. Results of pre- and postoperative transesophageal echocardiogram for patients having mitral valve repair for mitral regurgitation

\begin{tabular}{lccccc}
\hline & \multicolumn{2}{c}{ Prerepair } & & \multicolumn{2}{c}{ Postrepair } \\
\cline { 2 - 3 } \cline { 5 - 6 } Mitral regurgitation & $\mathbf{n}$ & $\%$ & & $\mathbf{n}$ & $\%$ \\
\hline None & 0 & 0 & & 680 & 75.0 \\
Trivial & 0 & 0 & & 202 & 22.2 \\
Mild & 0 & 0 & & 24 & 2.6 \\
Moderate & 62 & 6.8 & & 0.2 \\
Severe & 846 & 93.2 & & 0 & 0.0 \\
\hline
\end{tabular}

versus those who are in sinus rhythm having MVP. ${ }^{25,30} \mathrm{~A}$ more recently published study of 2821 Mayo Clinic patients documents higher operative mortality for AF patients, ${ }^{24}$ data that are supported by Alexiou and colleagues. ${ }^{26}$ However, differences in baseline characteristics between patients with/without AF may have confounded these results. Our data, in a multivariate logistic regression model, clearly demonstrate that preoperative AF is an independent predictor of operative mortality following MIMVS. This strengthens the argument for early operative intervention in mitral valve disease prior to the development of AF.

Aortic dissection associated with a minimally invasive approach may occur either at the site of aortic occlusion, be it endoaortic or transthoracic, or from the femoral cannulation site through retrograde malperfusion. Although the incidence of dissection and strokes was higher with EABO in our series, these differences were not statistically significant. In the first Port Access International Registry (PAIR) report, the incidence of aortic dissection was $1.3 \%$ in the first half of the study compared with $0.2 \%$ in the second half, a difference attributable to experience, better techniques, and improved technology particularly balloon design. ${ }^{10}$ Grossi and colleagues, ${ }^{9}$ Casselman and associates, ${ }^{8}$ and Onnasch and coworkers ${ }^{31}$ reported dissection rates of $0.3 \%(2 / 714)$, $0.7 \%(2 / 306)$, and $1.4 \%$ (3/209) with EABO, and the latter also reported a significantly higher incidence of neurologic complications with EABO compared with the transthoracic clamp. These concerns led the authors to abandon EABO for primary mitral valve procedures. ${ }^{31}$ Although, operative times are longer with EABO, a finding that has been mirrored by other smaller studies, ${ }^{32,33}$ this does not have a negative influence on the valve repair rate. These studies also demonstrated fewer technical difficulties and complications, less blood loss, and lower costs using the transthoracic clamp. Our data also demonstrate a longer postoperative stay with EABO. However, as EABO is predominantly used at 1 center, differing institutional practices may be a confounding variable.

Aortic dissection and atrioventricular groove disruption were the commonest reasons for conversion to sternotomy in our series, which occurred in $1.6 \%$ of patients. Conversion to median sternotomy generally occurs infrequently during the right minithoracotomy approach and others have reported this in $0.3 \%,{ }^{7} 1.1 \%,{ }^{9}$ and $2.0 \%{ }^{8}$ of patients. For the upper-hemisternotomy approach, this complication has been reported in $2.4 \%$ to $2.6 \%$ of patients, mostly due to bleeding, refractory arrhythmias, or ventricular dysfunction, whereas for the lower-hemisternotomy approach, this occurred in $4.0 \%$ of patients, most commonly due to poor exposure. $^{34,35}$

A reduction in postoperative hemorrhage, transfusion requirements, and need for reexploration for bleeding have been suggested as potential advantages of minimally invasive valve surgery due to a reduction in surgical trauma. This benefit is important given the significant morbidity and mortality associated with transfusions and reexploration. $^{36}$ Our data show that $45.5 \%$ of patients needed transfusion of blood or blood products (MVP $40.7 \%$, MVR 64.6\%). Reexploration for bleeding occurred in $5.4 \%$ of patients; other similar studies have reported this in $4.9 \%,,^{9} 5.1 \%,{ }^{7}$ and $8.5 \%$ of patients. ${ }^{8}$ The STS database between 1994 and 2003 reported this in $5.5 \%$ of all valvar procedures. ${ }^{18} \mathrm{~A}$ recently reported meta-analysis of MIMVS did, however, suggest a significantly reduced need for reoperation for bleeding compared with median sternotomy. ${ }^{37}$ In the majority of cases, the source of bleeding was from the chest wall and, in all cases, reexploration was accomplished safely through the

TABLE 6. Postoperative outcomes and complications

\begin{tabular}{|c|c|c|c|c|}
\hline Variable & Overall $(n=1178)$ & Repair (n = 941) & Replacement $(\mathbf{n}=237)$ & $P$ value \\
\hline Ventilator time $(\mathrm{h})$, median (IQR) & $7.6(4.0-12.0)$ & $7.0(4.0-11.0)$ & $10.0(7.0-18.0)$ & $<.0001$ \\
\hline New-onset atrial fibrillation $(\%)$ & 26.7 & 25.4 & 32.6 & .08 \\
\hline Permanent stroke $(\%)$ & 2.0 & 1.9 & 2.1 & .84 \\
\hline Transfusion $(\%)$ & 45.5 & 40.7 & 64.6 & $<.0001$ \\
\hline Reoperation for bleeding $(\%)$ & 5.4 & 5.1 & 6.8 & .32 \\
\hline Infection $(\%)$ & 0.6 & 0.5 & 0.8 & .58 \\
\hline Aortic dissection $(\%)$ & 0.8 & 0.6 & 1.3 & .32 \\
\hline Hospital length of stay (d), median (IQR) & $6(5-8)$ & $6(4-7)$ & $7(5-10)$ & $<.0001$ \\
\hline Mortality (\%) & 2.6 & 2.1 & 4.6 & .03 \\
\hline
\end{tabular}

$I Q R$, Interquartile range. 
TABLE 7. Multivariate analysis of predictors of mortality

\begin{tabular}{lclc}
\hline \multicolumn{1}{c}{ Variables } & OR & \multicolumn{1}{c}{$\mathbf{9 5} \%$ CI } & $\boldsymbol{P}$ value \\
\hline NYHA III or IV & 3.62 & $1.29-10.16$ & .01 \\
Diabetes & 2.81 & $1.19-6.65$ & .02 \\
Prolonged CPB time & 2.63 & $1.15-6.00$ & .02 \\
Preoperative atrial fibrillation & 2.53 & $1.08-5.90$ & .03 \\
Age $>70$ y & 2.29 & $1.02-5.15$ & .04 \\
Mitral valve replacement & 2.54 & $0.67-3.57$ & .31 \\
Hypertension & 2.34 & $0.99-5.52$ & .05 \\
Tricuspid valve procedure & 1.47 & $0.50-4.28$ & .48 \\
Previous cardiac surgery & 1.13 & $0.49-2.60$ & .77 \\
Pulmonary hypertension & 0.98 & $0.44-2.15$ & .95 \\
\hline$C P B$, Carion
\end{tabular}

$C P B$, Cardiopulmonary bypass; $C I$, confidence interval; $N Y H A$, New York Heart Association functional class; $O R$, odds ratio. C-statistic $=0.86$.

original minithoracotomy incision without the need for conversion to sternotomy. From a technical aspect, we have found a $30^{\circ}$ videoscope and dental mirror useful adjuncts for assessing chest wall hemostasis.

In summary, video-assisted MIMVS is safe and associated with a high rate of repair, low perioperative morbidity, and excellent early echocardiographic results. When compared with the transthoracic clamp, the EABO technique had a higher incidence of aortic dissection and strokes, although these differences did not reach statistical significance. Reoperative surgery, after a previous median sternotomy, was not an independent predictor for mortality, suggesting that the minithoracotomy approach may be superior to sternotomy in terms of early outcomes. Preoperative AF was an independent predictor of mortality, demonstrating that operative risk is increased if surgery is delayed until the onset of AF.

We acknowledge the enormous contributions of Jeanne Fox and Linda Kindell in data collection.

\section{References}

1. Walther T, Falk V, Metz S, Diegeler A, Battellini R, Autschbach R, et al. Pain and quality of life after minimally invasive versus conventional cardiac surgery. Ann Thorac Surg. 1999;67:1643-7.

2. Cohn LH, Adams DH, Couper GS, Bichell DP, Rosborough DM, Sears SP, et al. Minimally invasive cardiac valve surgery improves patient satisfaction while reducing costs of cardiac valve replacement and repair. Ann Surg. 1997;226:421-6; discussion 7-8

3. Baldwin JC. Editorial (Con) Re Minimally invasive port-access mitral valve surgery. J Thorac Cardiovasc Surg. 1998;115:563-4.

4. Felger JE, Chitwood WR Jr, Nifong LW, Holbert D. Evolution of mitral valve surgery: toward a totally endoscopic approach. Ann Thorac Surg. 2001;72:1203-8; discussion 8-9.

5. Casselman FP, Van Slycke S, Dom H, Lambrechts DL, Vermeulen Y, Vanermen H. Endoscopic mitral valve repair: feasible, reproducible, and durable. J Thorac Cardiovasc Surg. 2003;125:273-82.

6. STS. Society of Thoracic Surgeons Fall 2007 Report; 2007.

7. Seeburger J, Borger MA, Falk V, Kuntze T, Czesla M, Walther T, et al. Minimal invasive mitral valve repair for mitral regurgitation: results of 1339 consecutive patients. Eur J Cardiothorac Surg. 2008.

8. Casselman FP, Van Slycke S, Wellens F, De Geest R, Degrieck I, Van Praet F, et al. Mitral valve surgery can now routinely be performed endoscopically. Circulation. 2003;108(suppl 1):II48-54.

9. Grossi EA, Galloway AC, LaPietra A, Ribakove GH, Ursomanno P, Delianides J, et al. Minimally invasive mitral valve surgery: a 6-year experience with 714 patients. Ann Thorac Surg. 2002;74:660-3; discussion 3-4.
10. Galloway AC, Shemin RJ, Glower DD, Boyer JH Jr, Groh MA, Kuntz RE, et al. First report of the Port Access International Registry. Ann Thorac Surg. 1999;67: 51-6; discussion 7-8.

11. Aybek T, Dogan S, Risteski PS, Zierer A, Wittlinger T, Wimmer-Greinecker G, et al. Two hundred forty minimally invasive mitral operations through right minithoracotomy. Ann Thorac Surg. 2006;81:1618-24.

12. Mihaljevic T, Cohn LH, Unic D, Aranki SF, Couper GS, Byrne JG. One thousand minimally invasive valve operations: early and late results. Ann Surg. 2004;240: 529-34; discussion 34.

13. Suri RM, Schaff HV, Dearani JA, Sundt TM 3rd, Daly RC, Mullany CJ, et al. Survival advantage and improved durability of mitral repair for leaflet prolapse subsets in the current era. Ann Thorac Surg. 2006;82:819-26.

14. Mehta RH, Eagle KA, Coombs LP, Peterson ED, Edwards FH, Pagani FD, et al. Influence of age on outcomes in patients undergoing mitral valve replacement. Ann Thorac Surg. 2002;74:1459-67.

15. Jamieson WR, Burr LH, Miyagishima RT, Janusz MT, Fradet GJ, Lichtenstein SV, et al. Reoperation for bioprosthetic mitral structural failure: risk assessment. Circulation. 2003;108(suppl 1):II98-102.

16. Potter DD, Sundt TM 3rd, Zehr KJ, Dearani JA, Daly RC, Mullany CJ, et al. Risk of repeat mitral valve replacement for failed mitral valve prostheses. Ann Thorac Surg. 2004;78:67-72; discussion 67-72.

17. Borger MA, Yau TM, Rao V, Scully HE, David TE. Reoperative mitral valve replacement: importance of preservation of the subvalvular apparatus. Ann Thorac Surg. 2002;74:1482-7.

18. Rankin JS, Hammill BG, Ferguson TB Jr, Glower DD, O'Brien SM, DeLong ER, et al. Determinants of operative mortality in valvular heart surgery. J Thorac Cardiovasc Surg. 2006;131:547-57.

19. Burfeind WR, Glower DD, Davis RD, Landolfo KP, Lowe JE, Wolfe WG. Mitral surgery after prior cardiac operation: port-access versus sternotomy or thoracotomy. Ann Thorac Surg. 2002;74:S1323-5.

20. Sharony R, Grossi EA, Saunders PC, Schwartz CF, Ursomanno P, Ribakove GH, et al. Minimally invasive reoperative isolated valve surgery: early and mid-term results. J Card Surg. 2006;21:240-4.

21. Bolotin G, Kypson AP, Reade CC, Chu VF, Freund WL Jr, Nifong LW, et al. Should a video-assisted mini-thoracotomy be the approach of choice for reoperative mitral valve surgery? J Heart Valve Dis. 2004;13:155-8; discussion 8.

22. Benjamin EJ, Wolf PA, D'Agostino RB, Silbershatz H, Kannel WB, Levy D. Impact of atrial fibrillation on the risk of death: the Framingham Heart Study. Circulation. 1998;98:946-52.

23. Stewart S, Hart CL, Hole DJ, McMurray JJ. A population-based study of the longterm risks associated with atrial fibrillation: 20-year follow-up of the Renfrew/ Paisley study. Am J Med. 2002;113:359-64.

24. Ngaage DL, Schaff HV, Mullany CJ, Barnes S, Dearani JA, Daly RC, et al. Influence of preoperative atrial fibrillation on late results of mitral repair: is concomitant ablation justified? Ann Thorac Surg. 2007;84:434-42; discussion 42-3.

25. Lim E, Barlow CW, Hosseinpour AR, Wisbey C, Wilson K, Pidgeon W, et al. Influence of atrial fibrillation on outcome following mitral valve repair. Circulation. 2001;104(12 suppl 1):I59-63.

26. Alexiou C, Doukas G, Oc M, Oc B, Swanevelder J, Samani NJ, et al. The effect of preoperative atrial fibrillation on survival following mitral valve repair for degenerative mitral regurgitation. Eur J Cardiothorac Surg. 2007;31:586-91.

27. Eguchi K, Ohtaki E, Matsumura T, Tanaka K, Tohbaru T, Iguchi N, et al. Pre-operative atrial fibrillation as the key determinant of outcome of mitral valve repair for degenerative mitral regurgitation. Eur Heart J. 2005;26:1866-72.

28. Ngaage DL, Schaff HV, Mullany CJ, Sundt TM 3rd, Dearani JA, Barnes S, et al. Does preoperative atrial fibrillation influence early and late outcomes of coronary artery bypass grafting? J Thorac Cardiovasc Surg. 2007;133:182-9.

29. Ngaage DL, Schaff HV, Barnes SA, Sundt TM 3rd, Mullany CJ, Dearani JA, et al. Prognostic implications of preoperative atrial fibrillation in patients undergoing aortic valve replacement: is there an argument for concomitant arrhythmia surgery? Ann Thorac Surg. 2006;82:1392-9.

30. Chua YL, Schaff HV, Orszulak TA, Morris JJ. Outcome of mitral valve repair in patients with preoperative atrial fibrillation. Should the maze procedure be combined with mitral valvuloplasty? J Thorac Cardiovasc Surg. 1994;107: 408-15.

31. Onnasch JF, Schneider F, Falk V, Mierzwa M, Bucerius J, Mohr FW. Five years of less invasive mitral valve surgery: from experimental to routine approach. Heart Surg Forum. 2002;5:132-5.

32. Aybek T, Dogan S, Wimmer-Greinecker G, Westphal K, Mortiz A. The micro-mitral operation comparing the Port-Access technique and the transthoracic clamp technique. J Card Surg. 2000;15:76-81. 
33. Reichenspurner H, Detter C, Deuse T, Boehm DH, Treede H, Reichart B. Video and robotic-assisted minimally invasive mitral valve surgery: a comparison of the Port-Access and transthoracic clamp techniques. Ann Thorac Surg. 2005;79: 485-90; discussion 90-1.

34. Tabata M, Umakanthan R, Khalpey Z, Aranki SF, Couper GS, Cohn LH, et al. Conversion to full sternotomy during minimal-access cardiac surgery: reasons and results during a 9.5-year experience. J Thorac Cardiovasc Surg. 2007;134:165-9.
35. Gillinov AM, Banbury MK, Cosgrove DM. Hemisternotomy approach for aortic and mitral valve surgery. J Card Surg. 2000;15:15-20.

36. Murphy GJ, Reeves BC, Rogers CA, Rizvi SI, Culliford L, Angelini GD. Increased mortality, postoperative morbidity, and cost after red blood cell transfusion in patients having cardiac surgery. Circulation. 2007;116:2544-52.

37. Modi P, Hassan A, Chitwood WR Jr. Minimally invasive mitral valve surgery: a systematic review and meta-analysis. Eur J Cardiothorac Surg. 2008.

Access to The Journal of Thoracic and Cardiovascular Surgery Online is reserved for print subscribers!

Full-text access to The Journal of Thoracic and Cardiovascular Surgery Online is available for all print subscribers. To activate your individual online subscription, please visit The Journal of Thoracic and Cardiovascular Surgery Online, point your browser to http://www.mosby.com/jtcvs, follow the prompts to activate your online access, and follow the instructions. To activate your account, you will need your subscriber account number, which you can find on your mailing label (note: the number of digits in your subscriber account number varies from 6 to 10 ). See the example below in which the subscriber account number has been circled:

\section{Sample mailing label}

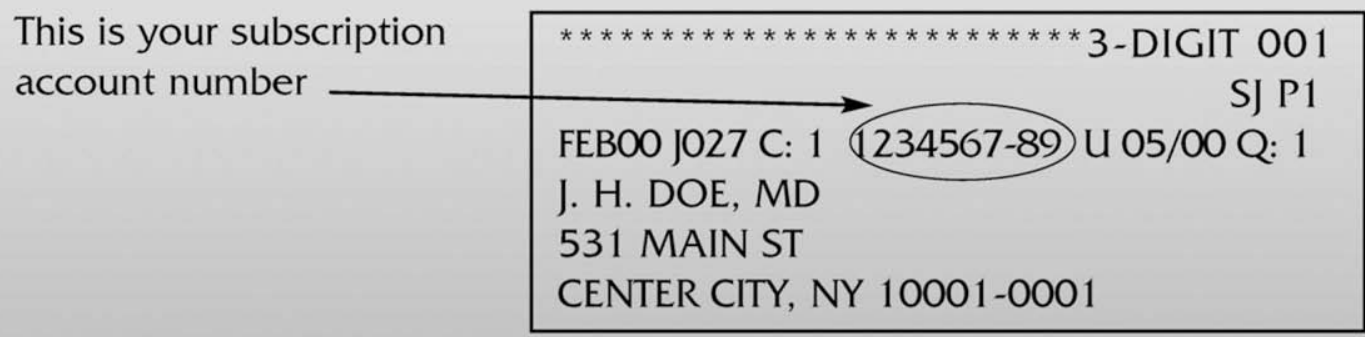

Personal subscriptions to The Journal of Thoracic and Cardiovascular Surgery Online are for individual use only and may not be transferred. Use of The Journal of Thoracic and Cardiovascular Surgery Online is subject to agreement to the terms and conditions as indicated online. 